\title{
Linking regional knowledge laboratory and growth of SMEs - empirical investigation in southern region of Poland
}

\begin{abstract}
The regional knowledge laboratory, being a part of the regional innovation system, impacts the regional innovation potential of regional firms, especially SMEs. Diffusion of innovations consists of the penetration of innovative solutions into the whole social and economic system, the result of which is a change in its functioning and overall development. The process of diffusion of innovations in a sense forces the innovativeness of the competing enterprises by necessitating their adaptation to the changing conditions of the environment. Diffusion of innovations is a determinant of the growth and development of enterprises, especially those of the SME sector. The paper is an attempt to empirically verifythe dependence between the development of small and medium-sized enterprises and the innovative potential of the studied region. Due to utilitarian reasons, the region was defined in accordance with the European statistical terminology (NUTS1 - regions in the total number of 6) as the area of two administration regions (NUTS2 - voivodeships in the total number of 16): małopolskie and śląskie, which makes of one statistical regional (PL2 - Southern Region of Poland). The empirical material was based on a random sample of 109 micro, small and medium-sized enterprises located in the studied region. With the use of computer statistical tools, the hypothesis made in the paper was confirmed, namely that the level of commercialization of knowledge and the transfer of technology in the studied region influences the development of small and medium-sized enterprises.
\end{abstract}

Keywords: innovation, knowledge laboratory, regional innovation system, business environment, knowledge \& technology transfer; SMEs

\section{INTRODUCTION}

In the era of the globalization of the economies, technological progress is important for the growth and development of firms. Yet, new ideas, innovations, technological advancements are not everything. The fundamental issue is the commercialization of the scientific and technical achievements, namely the transfer of these achievements into the market, which consists of passing technical and organizational knowledge in order to use it for the economic purposes (Wach, 2005: 117-133); (Sieja, Tomczyk, Wach, 2002: 481-496). It is a natural source of innovative development of companies. Insufficient financial resources and HR potential of small and medium-sized enterprises are an obstacle that prevents them from undertaking 
independent research. Cooperating with colleges and universities, especially technical ones, as well as state research institutions, may be a solution to this problem. Technological parks, innovation centres, or clusters of enterprises may be examples of the activities that support the transfer of knowledge and technology (Surdej, Wach 2008: 70-74). In particular, they are desired in the case of small and medium-sized innovative firms. Regional innovative potential is closely connected with the theory of diffusion of innovations.

The paper is an attempt to empirically verify the dependence between the growth and development of small and medium-sized enterprises and the innovative potential of the studied region. The research objective of the paper is to verify the real impact of the knowledge and technology transfer within the regional business environment on the growth and development of SMEs. The two main research methods were applied: literature review, criticism and synthesis, as well as a survey conducted among 109 firms.

\section{Theoretical Background - Literature REVIEW}

The knowledge laboratory or the regional knowledge laboratory is a very interesting concept linking the regional innovation system and the innovative potential of small and medium-sized enterprises and their growth (Sotarauta, Kosonen, 2005: 15-16; Langendijk 2001, pp. 136-155). The concept is based on the knowledge and technology transfer and innovation intermediaries, as well as innovation diffusion and innovation systems. The knowledge laboratory can be investigated on different levels (e.g. national, regional, local).

\section{The Concept of the Environment for Innovations}

The factors conditioning the innovative activity of an enterprise can be grouped into the internal and external ones (Romijn, Albu, 2001: 24). The internal factors concern the specificity of a single and individual organization, its goals, resources and management systems, they define its competences, the ability to work towards the improvement of innovativeness. B. Laperche and Z. Liu (2013) introduce a very interesting concept of the knowledge-capital, which is explained "the set of scientific and technical knowledge and information produced, acquired, combined and systematized by one or several firms for productive purposes" (Laperche, 2007: 24; Laperche et al., 2011: 1321). In their model, the concept of knowledge-capital (Fig. 1) links the external and internal factors by referring to the accumulated knowledge of one or several linked firms, which is continuously enriched by information flow and which is used in the production process or, more globally, in the process of the creation of value, which is dynamic.

On the other hand, the external factors result from the character and the specificity of the environment in which the organization functions, and define the amicability of the environment for innovativeness. These factors may influence the organization and its innovativeness both directly and indirectly. Finally, interactions should take place between the organization and its environment, creating an efficient system of the exchange of information 
and resources with the use of effective instruments. The managerial staff is responsible for shaping the internal factor group, whereas the appropriate administrative bodies of a region, country or the EU are responsible for shaping the environment for the benefit of innovativeness. In the case of building a system of interactions, the responsibility falls on both of them, but the involvement of enterprises should be increased due to the awareness of playing the role of a direct beneficiary, whereas on the part of the administrative bodies, it should be due to the sense of responsibility, greater opportunities and achieving long-term benefits from the established cooperation.

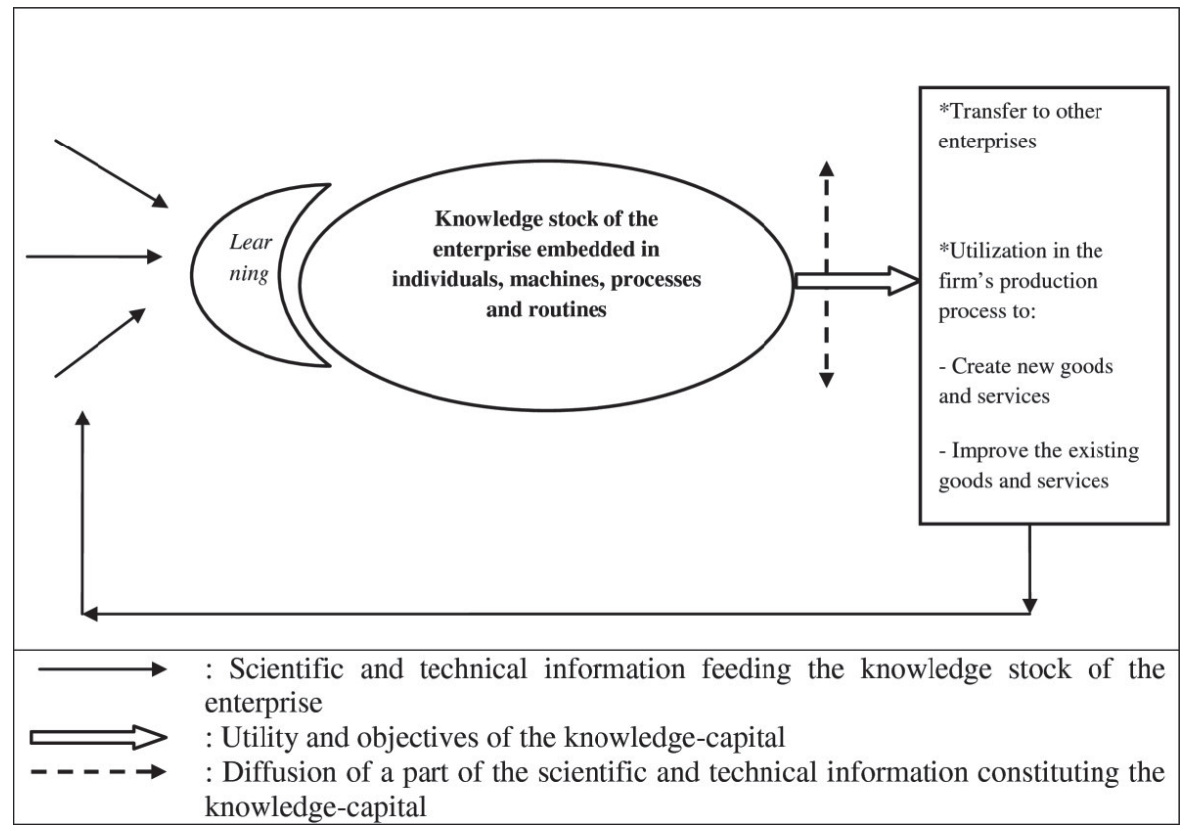

Fig. 1. Knowledge-capital concept linking internal and external environment for innovation

Source: Laperche, Liu (2013: 2)

The external factors influencing the innovative abilities of enterprises, and the process of diffusion of innovations towards entities introducing the innovative solutions to the market, may be discussed on the macro level (factors underlying the general environment), the micro level (factors underlying the competitive environment), and the meso level (factors occurring in the regional environment) (Wach, 2008: 35, 67).

By the end of the 1980s, the regional factors were ascribed key significance for the development of small and medium-sized enterprises, sometimes even bigger than the national conditioning (Hart, 2003: 12). However, it is worth stressing that regional factors had been taken into account before, by A. Smith and A. Marshall (Porter, 1998: 12). A lot of sources in the literature indicate strong dependence of small and medium-sized enterprises on regional factors. One of the representatives of the regional approach in the enterprise management is M.E. Porter (2002a, 2002b). According to this author, individual regions compete in offering 
the most beneficial business environment, in which the public and the private sector play different but mutually related roles in the creation of the economic growth (Porter, 2002b: 3). Although an adequate macroeconomic policy of the state conditions the economic growth, it is not sufficient, since the economic growth and competitive conditions ultimately depend on the conditions and the potential of the meso-environment (Porter, 2002b: 5). Moreover, M.E. Porter noticed a process of the shifting responsibility for the economic development, particularly in the region. We are moving away from the single-entity understanding of the economic growth which lies within the competence of state authorities. Nowadays, the conditioning of the economic growth is understood as a process, in which there exists cooperation between various entities, including state authorities on various levels, companies, scientific and research institutions, as well as educational institutions and cooperating and supporting institutions (Porter, 2002: 22). According to M.E. Porter, the quality of the regional business environment is not sufficiently considered neither by scientists nor regional authorities. In his numerous research, he adopts the division of the regional environment into four broadly understood areas: resource conditioning, demand conditioning, the context of an enterprise activity, and related and supporting industries (Porter et al., 2001b: X-XI); (Porter et al., 2001a: XIV). The mentioned elements create the so-called diamond of competitive advantage in the region. However, the elements have to mutually strengthen and complete each other, as they create a system. For example, regional competition stimulates the development of unique specialized competences and attracts specialized suppliers. Active local competitiveness also reinforces regional demand through crating more demanding customers. On the one hand, this model has a utilitarian character, since it defines the required features of the regional environment factors, and at the same time, it has a pragmatic significance for the creation of proper policy by the local authorities for the development of local entrepreneurship.

The problem of the regional environment preoccupies the minds of the scientists of different fields. When analyzing the conditionings of the functioning of innovative enterprises' in a given region, one should refer to numerous concepts of regional development, and, among others, to the Marshall concept of the industrial district, or the concept of the territorial production systems, being the derivative of the former one. Similarly, there is an analogical situation in the case of the innovative milieu model, which was introduced in 1980s by the French regionalist Ph. Aydalot (1986), and then developed by a research group GREMI (Groupe de Recherche Européen sur les Milieux Innovateurs), by, among others, a Swiss regionalist D. Maillat (2002). On the other hand, I. Pietrzyk (2002: 60) now observes the appearance of a new paradigm of the territorial development based on the primacy of non-material factors, because "when choosing the localization, more and more often enterprises are guided by innovative and organizational abilities of the local environment. [...] At present, however, there are no premises to judge whether and which of the organizational forms may win in the new technical and industrial paradigm". It should be admitted that the regions defined as territorial production systems or innovative environments are a source of competitive advantage for micro, small and medium-sized enterprises concentrated there, especially family-owned and craft-related. Providing the conditions necessary for the existence of innovative environment on the regional level leads to the creation of innovative 
enterprises, namely to establishing innovative businesses being the emanation of the local environment (Weresa, 2014).

In their empirical research, R. Sternberg and O. Arndt (2000: 3-7) considered the influence of innovative environment on the survival of small and medium-sized enterprises. External conditions in the environment of small and medium-sized enterprises are divided into regional and supra-regional factors. However, the Authors pay attention to the fact that it is not possible to exactly eliminate the factors of the regional environment, the factors of the macro-environment, and the factors related to the innovative policy, which may be included both in the regional and general factors. A similar concept may also be found in other research (Meyer-Krahmer, Gundrum, 1995: 177-185).

An interesting concept is also presented by A. Langendijk (2001: 136-155), who mentions regional factors, which he calls regional knowledge laboratory, among the factors conditioning the development of the learning organizations. Similarly, O. Pfirrmann (1994: 27-41) indicates that innovative activities of small and medium-sized enterprises are shaped by regional factors. Ch. Oughton, M. Landabaso and K. Morgan (2002: 97-110) also prove in their research that innovative activities of enterprises and their development are influenced by regional factors to a great extent. They call this phenomenon the regional innovative paradox.

The findings of the research carried out by German scientists in ten regions of Germany, within the framework of the Regional Entrepreneurship Monitor (REM) project, are interesting. Although this is a research of a utilitarian character, it has considerable value for the explanation of the impact the factors of the regional business environment have on the formation and development of micro, small and medium-sized enterprises. H. Bergmann, A. Japsen and Ch. Tamásy (2002) from Germany were among the first scientists to take into account the conditioning of the development of small and medium-sized enterprises on the regional level on such a scale in the research (REM). They isolated nine areas of the regional environment, which they called the framework conditions related to the establishment of new businesses, including a few factors conditioning the innovativeness of enterprises. They are, among others, (Bergman, Japsen, Tamásy, 2002: 21):

- the transfer of knowledge and technology to small and medium-sized enterprises,

- the quality of education and lifelong learning, taking into account the specific needs of potential entrepreneurs,

- the accessibility of advisory and business services for small and medium-sized enterprises,

- the accessibility of highly-qualified staff on the local labour market.

The spread of innovations depends on the identification of these factors and their impact. Considering the fact that several factors may have an influence at the same time, it is very difficult to establish which impact is subject to accumulation or abolishment,. Moreover, feedbacks may occur between individual factors, which may mean that the same factors influencing the popularization of a given innovation have very diverse significance in different countries. For example, technical conditioning results from the laws of technique development and from the characteristic features of individual innovations, while technical 
development on the one hand consistsof the differentiation and simplification of operations, and on the other hand of their integration. The development of the specialization processes is accompanied by the increase in cooperation, and these processes may have both a hindering and stimulating effect on the popularization of an innovation.

In most cases, another important aspect of the diffusion process is its dependence on the application and popularization of many other innovations, and it can result in the inability to introduce the innovation by the final producer, if the partial innovations are not introduced before by the co-operators. The final producer, dependent on the co-operators, is only trying to force innovations through the cooperative chain (Byrski, 1986: 127).

\begin{tabular}{|c|c|c|}
\hline $\begin{array}{l}\text { Macro-environment: } \\
\text { - globalization and } \\
\text { regionalization processes } \\
\text { - internationalization and } \\
\text { Europeanization processes, } \\
\text { - intensification of } \\
\text { competition and market } \\
\text { gambling, } \\
\text { - technical progress, } \\
\text { - the state of the activeness } \\
\text { of the economy, } \\
\text { - the scope of patented } \\
\text { inventions, } \\
\text { - state policy of the state } \\
\text { towards innovations, } \\
\text { - public expenditure on R\&D }\end{array}$ & $\begin{array}{l}\text { Meso-environment: } \\
\text { - distribution of various } \\
\text { attitudes towards } \\
\text { innovations, } \\
\text { - regional system of } \\
\text { innovations, institutional } \\
\text { support, } \\
\text { - policy of territorial } \\
\text { authorities, } \\
\text { - accessibility to qualified } \\
\text { human resources in the } \\
\text { region, } \\
\text { - regional research facilities, } \\
\text { including the transfer of } \\
\text { knowledge and technology, } \\
\text { - expenditure on R\&D in the } \\
\text { region }\end{array}$ & $\begin{array}{l}\text { Micro-environment: } \\
\text { - the method of the } \\
\text { organization of industry } \\
\text { and the character of } \\
\text { competition related to it, } \\
\text { - support and intensification } \\
\text { of cooperation and } \\
\text { coopetition, } \\
\text { - influence of other } \\
\text { participants of networks } \\
\text { and/or clusters, } \\
\text { - expenditure of R\&D in the } \\
\text { industry }\end{array}$ \\
\hline \multicolumn{3}{|c|}{ Exogenous Factors underlying in the External Environment } \\
\hline \multicolumn{3}{|c|}{$\downarrow \downarrow \downarrow$} \\
\hline \multicolumn{3}{|c|}{ DIFFUSION OF INNOVATIONS } \\
\hline \multicolumn{3}{|c|}{$\uparrow \uparrow \uparrow$} \\
\hline \multicolumn{3}{|c|}{ Endogenous Factors underlying in the Internal Environment } \\
\hline \multicolumn{3}{|c|}{$\begin{array}{l}\text { - the attitude of the managers and the staff to innovations } \\
\text { - qualifications of the employees, creativity of the design teams, and corporate entrepreneurship, } \\
\text { - accessibility to the enterprise financial resources necessary to implement the innovation, } \\
\text { - economic profitability of the innovation for the enterprise, } \\
\text { - the scale of minimum expenditure necessary to complete the innovation, } \\
\text { - technical complexity of the venture, } \\
\text { - the degree of machine and device wear and tear - it is thought that the bigger wear and tear is, } \\
\text { the stronger the stimuli to implement innovations are, }\end{array}$} \\
\hline
\end{tabular}

Fig. 2. Factors influencing the innovation diffusion process

Source: Kosała, Wach (2013: 122) 
To sum it up, the factors conditioning the phenomenon of diffusion may be divided into two groups: endogenous ones, namely the ones directly related to the innovation itself, (its characteristic features being relative advantage, complexity, compatibility, transmissibility), and exogenous ones, resulting from the conditions and properties of the environment in which the process of diffusion occurs, for example social, legal standards, conditions of communication or mental features of the recipients (Fig. 2).

Out of the external factors influencing the diffusion process, the impact of the state of the economic activity is the most controversial. In the literature on the subject, three different standpoints concerning the assessment of this factor occur (Baruk, 2001: 107). According to one of them, fast diffusion is sustained by the period of the peak expansion of production (B. Keirstead, C. Carter, B. Williams, B. Gold). According to another one, diffusion proceeds the fastest in the moments of the biggest deterioration of the economic situation (E. Graue, D. Aldcroft, H. Richardson, S. Hardy), yet another view assumes the average state of the economic situation as the best conditions to popularize innovations (E. Mansfieid). The presented views confirm the enormous complexity of the phenomenon of diffusion, resulting from the multiplicity of relations and their complexity within the framework of factors which condition them.

The institutional innovation system is one of the most important external factors in the innovation of the firm (Rachwał, 2012: 135-152). This institutional innovation base is a kind of catalyst for business innovation in situations where cooperation and networking are essential in order to achieve economies of scale and integrate a variety of skills, technologies and competencies needed to succeed in business applications of innovative solutions. Both the managers and the policy-makers should be aware that in order to exploit this complementarity, which, incidentally, will be transformed into a competitive advantage, both R\&D centres and innovation networks must be skilfully created and shaped. R\&D facilities are among the relevant factors in the institutional innovation, their impact on the level of innovation is spatially diverse. According to the model base of institutional innovation, R\&D facilities significantly stimulate the innovation economy. R\&D is per se a key driver of innovation and productivity of firms, even without a well-established and implemented network approach. The complementarity network of institutional systems and the level and the intensity of innovation in economic entities is confirmed in the literature, with most research only confirming the indirect complementarity or non-strict complementarity (Mancinelli, Mazzanti, 2009: 567-597). The role of the so-called knowledge and technology providers may therefore be either active or passive. In practice, we have to deal with at least three mechanisms for the transfer of knowledge and technology (Jershina et al., 2009: 51):

- transfer between firms (inter-firm transfer),

- transfer to firms from independent established R\&D centres,

- transfer to firms through intermediaries.

The innovation intermediaries constitute an important element in the transfer and diffusion of innovation from research centres to firms, as they take various measures in the innovation process, i.e. diagnosis demand for technology, purchase of technology, new adaptations of technology solutions, processing knowledge, mediation in the purchase of technology, 
commercialization of legal knowledge or technology. J. Howells, reviewing empirical studies of various authors, observed heterogeneity in the naming of such intermediaries (Howells 2006: 718, Stewart, Hyysalo, 2008: 289-299):

- intermediaries (eg. D. Watkins, G. Crawley, 1986; R. Seaton, M. Cordey-Hayes, 1993; M. Callon, 1994; S. Shohert, M. Prevezer, 1996),

- innovation intermediaries (eg. J. Howells, 1999),

- brokers (eg. HE Aldrich, MA von aluminum, 1992),

- knowledge brokers, knowledge brokering (eg. A. Hargadon, 1998; JD Wolpert, 2002),

- technology brokers, technology brokering (eg. KG Provan, SE Human, 1999;

A. Hargadon, Sutton RI 1997),

- intermediary agencies (eg. D. Braun, 1993),

- third parties (eg. SJ Mantel, G. Rosegger, 1987)

- innovation consultancy services (eg. L. Pilogret, 1993)

- consultants as bridge builders, bridging innovation (eg. J. Bessant and H. Rush, 1995;

D. Czarnitski, A. Spielkamp, 2000)

- intermediary firms (eg. R. Stankiewicz, 1995),

- level intermediary bodies (eg. B. van der Muelen, A. Rip, 1998),

- bricoleur (eg. T. Turpin, S. Garrett -Jones, N. Rankin1996)

- superstructure organization (eg. LH Lynn, NM Redd, JD Aram, 1996),

- boundary organizations (eg. DW Cash 2001; DH Guston 1999),

- knowledge intermediaries (eg. C. Millar, CJ Choi, 2003),

- regional Institutions (eg. B. McEvily and A. Zaheer, 1999).

\section{The Concept of Innovation Diffusion and Innovation Intermediaries}

Diffusion is a notion taken from hard sciences. By means of this notion, the phenomenon of spontaneous equalization of fluids, gases, solids as a result of the movement of particles was defined. In the economic science, the phenomenon describes the popularization or spread of all kinds of thought (knowledge) or matter (product). S. Gomułka (1990: 79) defines diffusion as the spread of a product or the method of its production. Diffusion is equated with the notion of popularization, which is the final stage of the innovative process and, economically, constitutes its very important part. Firstly, it enables enterprises to create innovative solutions in order to compensate for the expenditures incurred by them, secondly, it influences the enhancement of overall social and economic development (e.g., of a branch, industry, social development).

Diffusion of innovations consists of the introduction of innovative solutions into the whole social and economic system, the result of which is a change in its functioning and overall development. The process of diffusion of innovations in a sense imposes the innovativeness on the competing enterprises by necessitating their adaptation to the changing conditions of the environment. The notion of social and economic system may be discussed as a frame involving the geographical range, which means that the diffusion of innovations may involve a system which is the enterprise itself, or the region in which it operates, or the spread to the national or international scale. 
K. Karcz presents the planes of the phenomenon of diffusion a little bit differently. In one of them he isolates the process of research, development and production in which innovation is subject to adequate transformation, enabling its materialization and commercialization. The transfer of innovations among enterprises in the country is another plane, and the spread has spatial dimension in this case. The third plane concerns the spread of innovations within the social system in which decisions about the absorption of innovations are taken by individual consumers (Karcz, 197: 25-26).

By this concept, the phases of the diffusion process were isolated, the initial phase concerning the sources of innovation and the stage of its implementation into the economic practice, the further one concerning the spread to the entities absorbing them, and the final stage concerning the changes evoked in the social system, being the effect of acceptation. It should be mentioned that some innovations do not spread on all indicated planes. Such a situation usually happens when a new product or technology does not succeed in the market. Then, the process of diffusion may be stopped at one of the mentioned levels. A similar situation applies to the geographical range of the diffusion process, when innovations important for the technical development are popularized in the global scale (Bogadienko, 1998: 8).

Diffusion needs time, which depends on the specific character of the conditioning of the system in which the process undergoes. The speed and the scope of innovation spread is influenced, among others, by (Byrski, 1986: 129-130):

- the degree to which the innovation surpasses the hitherto prevailing processes or products in regard to economic benefits (profitability, utility values, probability to meet the needs in compliance with the expectations, etc.)

- the volume of necessary investment expenditure and other financial outlays,

- demand for the innovative goods,

- the level of risk related to the application of a new product,

- the level of the concentration of production,

- the size of industrial enterprises introducing the innovation and the dynamics of their production,

- the efficiency of various forms of the innovation's spread, especially the system of information.

At present, we can observe a trend of shortening the time of diffusion of innovations, which in practice means faster introduction and adaptation of innovative solutions. It stems from the growing dynamics of changes occurring in the environment of every enterprise and a necessity to adapt to them by the ones that want to function, develop and compete in the market. As the process of diffusion occurs in the social and economic system, in rare cases it concerns the area of single corporations, so there is a possibility to influence the speed of diffusion by creating appropriate conditions.

One of the most prominent frameworks of the adoption of an innovation used is Rogers' (1995, 1976: 290-305) theory of diffusion of innovations (Fig. 3). In E.M. Rogers' concept, diffusion is the process by which an innovation is transmitted through certain channels over time among the members of a social system. Each member of the social system faces their own innovation-decision that follows a 5-step process (1995: 162): 
1) Knowledge - a person becomes aware of the innovation and has some idea of how it functions,

2) Persuasion - the person forms a favorable or an unfavorable attitude towards the innovation,

3) Decision - the person engages in activities that lead to a choice to adopt or reject the innovation,

4) Implementation - the person puts the innovation into use,

5) Confirmation - the person evaluates the results of an innovation - decision already made.

.:. antecedents :...

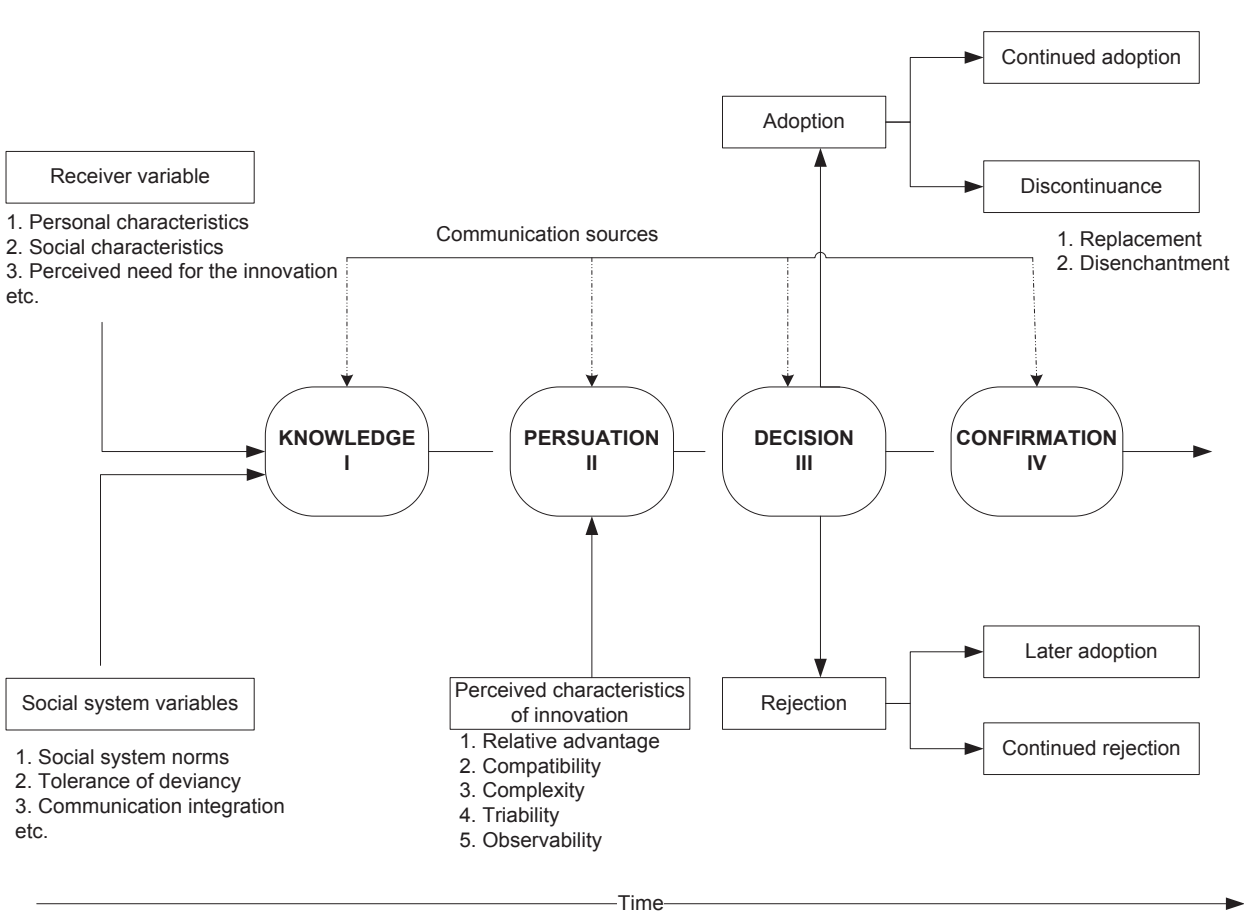

Fig. 3. Innovation Diffusion Conceptual Model of E.M. Rogers

Source: Rogers (1995: 4).

E.M. Rogers (1995: 5-16) considers the following as the major indicators of the process of diffusion of innovations: innovation and its features, communication channels (links mediating in the exchange of information), time needed to make a decision, adaptation, and social environment, which he sees as a set of individuals in a given system, their mutual connections and characteristic relations. At the same time, he draws attention to the role of attributes of innovations, which determine the degree and the speed of their diffusion. These are (Rogers, 1995: 5-16): 
- relative advantage - a degree to which the innovation is perceived as better than the ones used so far,

- compliance with the existing values, experience so far, and the needs of potential adopters,

- easiness of application - a degree to which potential adopter perceives an innovation as difficult to understand and to use,

- anopportunity to experiment (testing, possible to introduce in stages)

- Innovations possessing the mentioned features are more easily acceptable by entities of a given social and economic system, which makes the diffusion time shorter.

- When analysing the complex phenomenon of the diffusion of innovations, we can distinguish some occurring regularities, namely (Byrski, 1986: 127):

- the faster the popularization of innovations is, the bigger their profitability is, and the smaller investment expenditure they need,

- innovations with a shorter period of investment returns promise faster speed of popularization,

- the influence of the same factor on the popularization of different innovations depends on their kind,

- in case of process innovations, a more important role is played by economic factors, whereas in case of product innovations, these are sociological factors,

- possible benefits from the later accession of a specific country to an innovation may depend on the technical complexity of the popularized invention.

The popularization of new and tested technical solutions in all kinds of possible areas of their application may have direct impact on the increase in the national income and, at the same time, it may constitute a leverage for the innovativeness development thanks to the social sense of its economic effectiveness.

When analysing the literature on the subject, we can state that the phenomenon of diffusion is a complex problem, concerning numerous research planes of subjective (who participates), objective and spatiotemporal character, creating innovations (imitating, improving), and increasing innovativeness of both individual economic entities and their environment. It is interesting to obtain an answer to the question about the rate of diffusion and its conditioning.

\section{Research Material and Methods}

The research objective of the paper is to verify the real impact of the knowledge and technology transfer within the regional business environment on the growth and development of SMEs. The two main research methods were applied: literature review, criticism and synthesis, as well as a survey conducted among 109 firms.

In the course of the study, the following research hypothesis was presented: "The level of commercialization of knowledge and the transfer of technology in the studied region has an influence on the growth and development of small and medium-sized enterprises". 
The two main research methods were applied: literature review, criticism and synthesis, as well as the survey (a postal questionnaire) conducted among 109 firms. The statistical calculations were made by means of the statistical software package "Statistica PL". In order to verify the assumed hypothesis, the following statistical tests were applied: Pearson's linear correlation, chi-square independence test (Yates correction), Student's t-test, non-parametric Mann-Whitey U test.

The two main variables were indicated: TRANSFER - knowledge and technology transfer as well as GROWTH - the growth and development of SMEs (Fig. 3). The first variable was measured by the managerial perception concerning the evaluation of the quality and the support of innovation diffusion by universities and higher schools, private and public research and development centres, as well as business education for entrepreneurship at secondary schools and colleges/universities. As the managerial perception was applied as the main research technique, both variables were also measured with the use ofother variables: the characteristics of the entrepreneur (their sex, level of education, experience in business, and entrepreneurial attitude) and the characteristics of the firm (its age, size, territorial range, and business scope of the firm). It must be stressed that it is not the conceptual model in concrete, it is just a research conceptual framework used only for the empirical purpose, to verify a small fragment of the wider context.

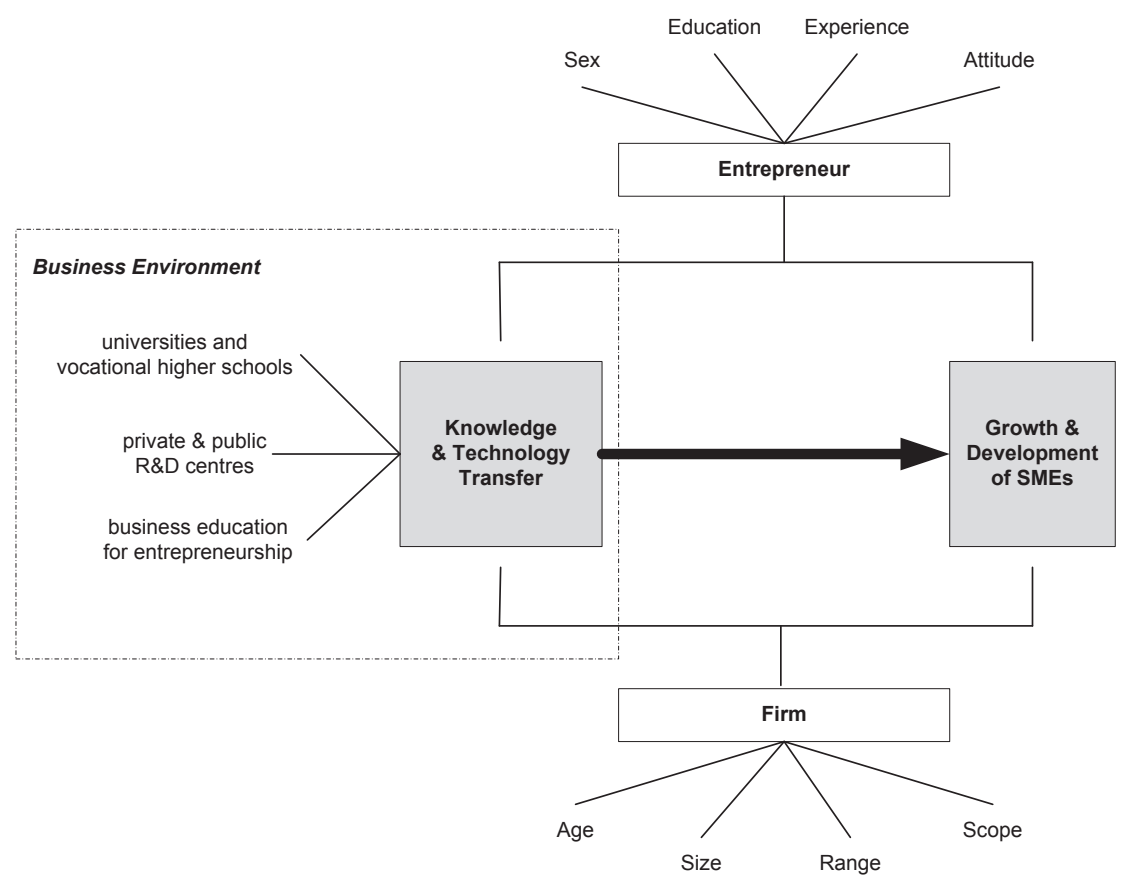

Fig. 4. Research Model - Conceptual Framework for the Empirical Research

Source: own study 
SAMPLING

The main objects of the research are micro, small and medium-sized enterprises. Due to problems with obtaining financial data (the data received were incomplete), only one factor was adopted as the distinguishing feature of a firm size, namely the size of employment. The identical solution is used by Eurostat - the Statistical Office of the European Union, as well as Central Statistical Office of the Republic of Poland (GUS), and by both domestic and international authors in the majority of empirical research (Sheikh, Pecher, Steiber, Heckl, 2002: 2). Due to that, the comparability of the conducted research results with already existing results is possible. The study was carried out on the stratified random sample of firms chosen from the National Official Business Register (REGON) base, and two strata were selected as distinguishing features: the size of employment in the firm, and the region in which the firm operates.

The research sampling was prepared by the Central Statistical Office - Divisions in Krakow and Katowice, within the framework of the ordered database. Depending on the number of workers, the studied firms were divided into: microenterprises (up to 9 employees); small enterprises (from 10 to 49 people); medium-sized enterprises (from 50 to 249 people). However, due to the specific needs of these entrepreneurs, we decided to isolate them as a separate category. The micro firm category was also considered in the research carried out by the Austrian Institute for SMEs Research (Sheikh, Pecher, Steiber, Heckl, 2002, p. 2).

The other stratum applied, due to the subject of the research, was the region (according to NUTS-1), but because of utilitarian reasons it was defined as an area of two administration regions (NUTS-2) in Southern Poland (małopolskie voivodeship, śląskie voivodeship). Yet, the choice was not accidental. According to the statistical classification binding in Poland, these regions constitute one region (PL2 - Region II, called the Southern Region of Poland).

It was assumed that at least 44 surveys would be conducted in each region. With the consideration of the previous research experience, it was assumed that the return rate for the surveys should fluctuate around 15\%. Taking these assumptions into account, 500 surveys were sent out (250 in each of the studied regions), supported by the telephone conversation requesting to take part in the survey, and 109 complete filled out surveys were received, which means that the return rate was $22 \%$. It is worth emphasizing that the size and the representativeness of the sample in Polish and foreign empirical research conducted in this scope have recently been fluctuating from 40 to over 1000, which proves the significance of the results based on a sample of 109 enterprises, however, this size is given on the basis of the study of the literature (Wach, 2007a; Wach, 2007b).

From each region constituting the Southern Region (PL2) the same number of enterprises was sampled, and sent the surveys, yet the real representation of individual regions in the studied sample is diverse (to a small extent), due to different return rates. The małopolskie region is represented by $44.95 \%$, and the śląskie region by $55.05 \%$ of the respondents. From the point of view of the statistical inference, the result should be considered as satisfactory, and at the same time not causing the overbalancingof the structure towards the representation 
of enterprises from one of the studied regions. Due to the character of the research, the sample was limited to the region as a whole, and not the group of regions, thus, all statistical inferences will be presented for a region, and not individual regions.

\section{EMPIRICAL RESULTS AND DISCUSSION}

In order to determine the influence of innovative potential of the studied region on the development of small and medium-sized enterprises located in it, two variables were constructed. To determine the level of development of the studied enterprises, the authors constructed an overall assessment index of enterprise development through the sum of values (the interval from 1 to 5) indicated by the respondents in each question, and then it was divided by the sum of the maximum values obtainable. Finally, the averaged total assessment was obtained, standardized in the interval from 0 to 1 (given in percentage in the interval from 0 to 100). The synthetic index took into account eleven sub-indices evaluating the level of development of the studied enterprises, namely the market share, sales growth, tangible resources, the size of employment, intangible and legal values, organization and management, financial liquidity, profitability, the value of equity, investments, the growth rate against the industry. The evaluations of the individual factors of the studied enterprises' development adopted continuous values in the closed interval $\langle 0 ; 100\rangle$, and the following values were adopted: $|0-25|-$ strong regression; $|26-50|$ - regression; $|51-75|$ - development; $|76-100|$ strong development. At the same time, the quasi continuous variable was obtained. For the needs of the analysis of the regional environment influence, related to the innovative potential of the studied region on the development of small and medium-sized enterprises in the studied region, a synthetic index of the evaluation of the level and quality of the transfer of knowledge and technology in the studied region (TRANSFER) achieved by the entrepreneurs was prepared. The index was constructed on the basis of the sum of values (the interval from 1 to 5) indicated by the respondents, and then it was divided by the sum of the maximum values obtainable. Finally, the averaged assessment, which was subject to standardization in the interval from 0 to 1 , was obtained (given in percentage in the interval from 0 to 100). At the same time, the quasi continuous variable was obtained ${ }^{1}$. The index was constructed on the basis of the managerial assessment of such factors as the quality

\footnotetext{
${ }^{1}$ The assessment of this factor adopted continuous values $(1,2,3,4 \ldots)$ in the closed interval $<0 ; 100>$, and the following values were adopted: $|0-25|$ - completely non-beneficial; $|26-50|$ - non-beneficial; $|51-75|-$ beneficial; $|76-100|$ completely beneficial. Such a division was determined by the rules of statistical inference and the easiness of drawing conclusions with the consideration of quartiles. The interpretations in this chapter are mainly based on continuous values due to bigger precision of their interpretation. Therefore, for the decription and interpretation of the phenomena to occur in the studied population, the techniques and methods of the descriptive statistics were used, such as: median, mode, its frequency, standard deviation, upper and lower quartile, minumum, maximum, as well as statistical graphic tools which serve to specify the interpretation, among them: box plot, histogram, two-dimensional frequency distribution. On the other hand, non-continuous values (completely non-beneficial, non-beneficial, beneficial, compeletely beneficial) presented mainly in the form of bar chart, serve as an approximate illustration of the observed phenomena and its regularities. Due to roundings, the values on particular charts may not achieve the total sum of $100 \%$.
} 
of scientific and research centres, the quality of universities and colleges, the assessment of the quality of services offered by technology and innovation transfer centres, and the assessment of the quality of services offered by technological and industrial parks. The indices constructed in such a way enabled to use the verification methods of the hypothesis both for qualitative data and continuous data.

The transfer of knowledge and technology as a factor in the regional business environment was assessed as high by the studied entrepreneurs (the maximum value was 93.3, and simultaneously in the studied population, among the assessments of nine other studied factors of the environment, the highest minimum value of 46.7 was observed). It may be proved on the basis of the arithmetic mean value $(\overline{\mathrm{x}}=72.3)$, and, primarily, the median (Me $=73.3$ ), which indicate that nearly half of the surveyed entrepreneurs assessed the feature TRANSFER as definitely beneficial. Moreover, in the studied population, the lowest standard deviation was observed against the remaining nine factors of regional environment $(\mathrm{s}=$ 10.5), which means that the average difference between the entrepreneurs' assessments and the arithmetic mean of the studied variable TRANSFER is low. On the basis of the standard deviation value we can draw a conclusion that the assessment of this factor is at the same time the least varied among the assessments of all the factors $(\min =46.7, \max =93.3)$. The most numerous group was made up of the entrepreneurs assessing this factor as beneficial $(\mathrm{Mo}=$ 66,7 , at 29 elements).

In the studied population, with the use of the Pearson's linear correlation, a strong positive correlation between the respondents' education (EDUCATION), and the assessment of regional factors connected with the transfer of knowledge and technology (TRANSFER) was observed, which proves the value of the statistics $r=0.48$ at the level of significance $\mathrm{p}=0.03$. The higher the level of the respondents' education, the higher is the frequency of positive assessments. However, on the basis of the conducted statistical calculations it is not possible to prove the dependence of the remaining features (SEX - the entrepreneur's sex, EXPERIENCE - the entrepreneur's business experience, ATTITUDE - the entrepreneur's entrepreneurial attitude, AGE - the age of the firm, SIZE - the size of the firm, SCOPE - the kind of the firm activity, RANGE - the firm territorial range of activity) on the evaluation of this factor (TRANSFER).

In order to check for the occurrence of the inter-dependence between the regional factors related to the transfer of knowledge and technology (TRANSFER), and the growth and development of small and medium-sized enterprises (GROWTH), the chi-square independence test was used. On the basis of the chi-square statistics, using the comparison of the elements of the theoretical (expected) frequency matrix and the elements of the empirical (observed) frequency matrix, the value of $x^{2}=6.4$ was obtained at the level of significance $\mathrm{p}=0.04$. Thus, we can claim that there is a statistically significant dependence between the regional environment factors related to the transfer of knowledge and technology, and the development of small and medium-sized enterprises. The studied enterprises which assess the influence of the transfer of knowledge and technology on the development of enterprises positively, at the same time show development more often (the percentage of such enterprise in the research sample is $74.7 \%$ ). 
The inferred dependence was also confirmed with the use of Yates correction, consisting of subtracting the number 0.5 from the module of the difference of the observed and hypothetical frequencies, before squaring this difference in order to improve the approximation of the statistic, which makes the statistical estimation more careful. With the use of the software, the result $\mathrm{x}_{\text {Yates }}^{2}=2.6$ was obtained at the permissible statistical significance of $\mathrm{p}=0.1$.

The studied variables TRANSFER and GROWTH had normal distribution in each of these populations, which enabled to use the Student's t-test. With the use of the parametric test of differences between the averages, the result $\mathrm{t}=2.26$ at the statistical significance $\mathrm{p}=$ 0.026 was obtained which means that the inferred dependence was also confirmed with the use of the Student's t-test.

To verify the hypothesis, the non-parametrical Mann-Whitney U test of the differences between two averages of the studied features TRANSFER and GROWTH was applied. On the basis of the calculations conducted, the results $U=91.5, Z^{\prime}=2.17$ were obtained at statistical significance of $\mathrm{p}=0.03$, which means that the significant statistical difference was found. It confirms the adopted hypothesis of the influence of regional factors connected with the transfer of knowledge and technology on the development of small and medium-sized enterprises.

\section{Conclusions}

The analysis of innovativeness in the chosen regions enables to draw conclusions about their innovative development determined by specific factors. Their detailed study enables to determine the areas functioning in the proper way from the perspective of the structure of the environment supporting the development of enterprise innovativeness, as well as the to identify the ones which are neglected and hinder the possibility of using the full potential.

On the basis of the results of the empirical research carried out by the Authors it was proved that the theoretical postulate about the existence of relation between the transfer of knowledge and technology in the studied region, and the development of small and medium-sized enterprises, was positively verified. The statement (made on the basis of the conducted research) that the factors of the regional environment related to the innovative potential of the region are fundamental in the development of small and medium-sized enterprises may be too far-fetched, yet we can certainly claim that those factors are one of the significant determinants in the development of the studied enterprises, and their analysis provides valuable clues as far as the further directions of changes in this scope are concerned. In the opinion of the entrepreneurs themselves, the factors of the regional environment play the third-rate role in the development of the studied enterprises $(76.5 \%)$, because in their opinion national conditioning has the leading impact $(96.2 \%)$, as well as the factors related to the entrepreneur and his entrepreneurial attitude (94.3\%). To sum up the considerations on the influence of innovative potential of the studied region on the development of small and medium-sized enterprises, we should draw the following conclusions: 
The level of the regional innovative potential of malopolskie and śląskie is high in the opinion of the studied entrepreneurs. It proves the existence of beneficial conditions lying in the regional environment for the growth and development of innovative enterprises.

The statistical verification of the hypothesis proved that there is a dependence between the evaluation of innovative assessment in the region and the transfer of knowledge and technology, and the development of the studied enterprises at the typical statistical significance $\left(x^{2}=6.4\right.$ at $\left.\mathrm{p}=0.04\right)$. On this basis, we can conclude that the studied level of innovative potential and the transfer of knowledge and technology in the studied region influences the growth and development of small and medium-sized enterprises positively.

\section{References}

Aydalot, Ph. (1986). Milieux innovation en Europe, Paris: GREMI.

Baruk, J. (2001). Organizacyjne uwarunkowania działalności innowacyjnej przedsiębiorstwa. In: Zarządzanie innowacjami technicznymi i organizacyjnymi, M. Brzeziński (ed.), Warszawa: Difin.

Bergmann, H., Jaspen, A., Tamásy, Ch. (2002). Regionaler Entrepreneurship Monitor (REM). Gründungsaktivitäten und Rahmenbedingungen in zehn deutschen Regionen. Köln-Lüneburg: Universität zu Köln, Universität Lüneburg.

Bogdanienko, J. (1998). Cechy procesów innowacyjnych lat dziewięćdziesiątych. In: Zarządzanie innowacjami, J. Bogadienko (ed.), Warszawa: Oficyna Wydawnicza Szkoły Głownej Handlowej.

Byrski, B. (1986). Procesy innowacyjne w przemyśle. Kraków: Wydawnictwo Akademii Ekonomicznej w Krakowie.

Gomułka, S. (1990). The Theory of Technological Change and Economic Growth. New York: Routledge.

Hart, D.M. (2003). Entrepreneurship Policy. What It Is and Where It Come From. In: The Emergence of Entrepreneurship Policy. Governance, Start-ups and Growth in the U.S. knowledge economy, D.M. Hart (ed.). Cambridge: Cambridge University Press.

Howells, J. (2006). Intermediation and the role of intermediaries in innovation. Research Policy, 35(5).

Jerschina, J., Wach, K. et al. (2009). Ocena transferu wiedzy i powiazań sfery $B+R$ oraz instytucji otoczenia biznesu z przedsiębiorstwami. Badanie ewaluacyjne on-going Regionalnej Strategii Innowacji. Raport końcowy. Kraków: Urząd Marszałkowski Województwa Małopolskiego.

Karcz, K. (1997). Proces dyfuzji innowacji - podejście marketingowe. Katowice: Wydawnictwo Akademii Ekonomicznej w Katowicach.

Kosała, M., Wach, K. (2011). Regionalne determinanty rozwoju innowacyjności przedsiębiorstw. Zeszyty Naukowe Uniwersytetu Ekonomicznego w Krakowie, 866.

Kosała, M., Wach, K. (2013). Czynniki determinujące dyfuzję innowacji na poziomie makro, mezo i mikro. In: Makroekonomiczne i sektorowe czynniki rozwoju przedsiębiorczości. K. Zieliński (ed.), Katowice: Wydawnictwo Naukowe Śląsk.

Langendijk, A. (2001). Regional learning between variation and convergence: The concept of 'mixedland-use' in regional spatial planning in the Netherlands. Canadian Journal of Regional Science, 24(1).

Laperche, B. (2007). Knowledge-capital and innovation in multinational corporations. Journal of Technology and Globalisation, 3(1), 24-41.

Laperche, B., Lefebvre, G., Langlet, D. (2011). Innovation strategies of industrial groups in the global crisis: rationalisation and new paths, Technological Forecasting and Social Change, 78(8), 1319-1331.

Laperche, B., Liu, Z. (2013). SMEs and knowledge-capital formation in innovation networks: a review of literature, Journal of Innovation and Entrepreneurship, 2(21). 
Maillant, D. (2002). Globalizacja, terytorialne systemy produkcyjne i środowiska innowacyjne. Rector's Lecture, 52, Kraków: Wydawnictwo Akademii Ekonomicznej w Krakowie.

Mancinelli, S., Mazzanti, M. (2009). Innovation, Networking and Complementarity: Evidence on SME Performances for a Local Economic System in North-Eastern Italy. The Annals of Regional Science, 43(3).

Meyer-Krahmer, F., Gundrum, U. (1995). Innovationsförderung im ländlichen Raum. Raumforschung und Raumordnung, 53(3).

Oughton, Ch., Landabaso, M., Morgan, M. (2002). The regional innovation paradox: Innovation policy and industrial policy. Journal of Technology Transfer, 27(1).

Pfirrmann, O. (1994). The Geography of Innovation in Small and Medium-sized Firms in West Germany. Small Business Economics, 6(1).

Pietrzyk, I. (2002). Polityka regionalna Unii Europejskiej i regiony $w$ państwach członkowskich, Warszawa: Wydawnictwo Naukowe PWN.

Porter, M.E. (1998). The Adam Smith Address: Location, Cluster, and the "new" Microeconomics of Competition. Business Economics, 33(1).

Porter, M.E. (2002a). Competitiveness and the Role of Regions, Paper at the conference. The Centre For Huston's Future, Huston, Texas, 22 November.

Porter, M.E. (2002b). Regional Foundations of Competitiveness. Issues for Wales, Paper at the conference. Future competitiveness of Wales: Innovation, Entrepreneurship and Technology Change, 3 April.

Porter, M.E. et al. (2001a). Clusters of Innovation: Regional Foundations of U.S. Competitiveness. Report. Washington: Harvard University.

Porter, M.E. et al. (2001b). Research Triangle. Clusters of Innovation Initiative. Report, Washington: Harvard University.

Rachwał, T., (2012). Innowacyjność przedsiębiorstw przemysłowych jako czynnik rozwoju miast. Studia Komitetu Przestrzennego Zagospodarowania Kraju PAN, 141, 135-152.

Rogers, E.M. (1976). New Product Adoption and Diffusion, Journal of Consumer Research, 2.

Rogers, E.M. (1995). Diffusion of Innovations, New York: The Free Press.

Romijn H., Albu M. (2001). Explaining Innovativeness in Small High-Technology Firms in the United Kingdom. Working Paper, 00.18, Endhoven: Endhoven Centre for Innovation Studies.

Sheikh, S., Pecher, I., Steiber, N., Heckl, E. (2002). Support Services for Micro, Small and Sole Proprietor's Businesses. Final Report Brussels - Vienna: European Commission - Austrian Institute for SMEs Research.

Sieja, M., Tomczyk, K., Wach, K. (2002). Rola Krakowskiego Parku Technologicznego w transferze innowacji: Handel międzynarodowy 2002. Stan i kierunki rozwoju. K. Budzowski, S. Wydymus (red.), Kraków: Katedra Handlu Zagranicznego Akademii Ekonomicznej w Krakowie.

Surdej, A., Wach, K., (2008). Rola parków naukowo-technologicznych w rozwoju małych i średnich przedsiębiorstw. Przedsiębiorczość - Edukacja, 4, 70-74.

Sotarauta, M., Kosonen, K.-J. (2005). Strategic adaptation to the knowledge economy in less favoured regions: a South Ostrobothnian University network as a case in point. In: Regional Economies as Knowledge Laboratories, Ph. Cooke, A. Piccaluga (eds.), Cheltnham - Northampton, MA: Edward Elgar.

Sternberg, R., Arndt, O. (2001). The firm or the Region - What Determines European Firms' Innovation Behavior?. Economic Geography, 77(4).

Stewart J., Hyysalo S. (2008). Intermediaries, Users and Social Learning in Technological Innovation. International Journal of Innovation Management, 12(3).

Wach, K. (2005). Współpraca małych i średnich przedsiębiorstw z ośrodkami naukowo-badawczymi na przykładzie Krakowskiego Parku Technologicznego. Zeszyty Naukowe Akademii Ekonomicznej w Krakowie, 671. 
Wach, K. (2007a). Empiryczna weryfikacja wpływu poziomu komercjalizacji wiedzy i transfery technologii na rozwój małych i średnich przedsiębiorstw Polski Południowej. Zeszyty Naukowe Politechniki Świętokrzyskiej. Nauki Ekonomiczne, 35.

Wach, K. (2007b). Wpływ potencjału innowacyjnego Małopolski i Śląska na rozwój małych i średnich przedsiębiorstw w świetle badań empirycznych. Wiedza i innowacje rozwoju polskich regionów: siły motoryczne i bariery, S. Pangsy-Kania (ed.). Gdańsk: Fundacja Rozwoju Uniwersytetu Gdańskiego.

Wach, K. (2008). Regionalne otoczenie matych i średnich przedsiębiorstw. Kraków: Wydawnictwo Uniwersytetu Ekonomicznego w Krakowie.

Weresa M.A. (2014). Polityka innowacyjna. Warszawa: Wydawnictwo Naukowe PWN.

Wiśniewska, J. (2004). Dyfuzja jako determinanta działalności innowacyjnej przedsiębiorstw. In: Innowacje $w$ rozwoju przedsiębiorczości w procesie transformacji, W. Janasz (ed.), Warszawa: Difin.

Krzysztof Wach - Associate Professor of Strategic and International Entrepreneurship. Habilitated doctor of economics (DEcon), Ph.D. in management, graduate and then associate professor at the Cracow University of Economics, a specialist in international entrepreneurship, an author of several books and over 150 scientific articles, a member of editorial boards of several scientific journals, including the annual 'Entrepreneurship - Education'; editor-in-chief of the scientific quarterly 'Entrepreneurial Business and Economics Review', an OECD national expert for entrepreneurship since 2012, participates of various international education and research projects (e.g. Jean Monnet, Atlantis, International Visegrad Fund IVF, Central European Initiative CEI), is a visiting professor in various American and European universities, including Grand Valley State University (Grand Rapids, USA), Roosevelt University (Chicago, USA), University of Detroit Mercy (Detroit, USA), Loyola University Chicago (Chicago, USA), Northumbria University (Newcastle, UK), Technical University of Cartagena (Cartagena, Spain).

\section{Adress:}

Uniwersytet Ekonomiczny w Krakowie

Katedra Przedsiębiorczości i Innowacji

ul. Rakowicka 27, 31-510 Kraków, Polska

e-mail:wachk@uek.krakow.pl

Malgorzata Kosała - Ph.D. in management within the specialisation of innovation management (2006), Master in Organisation and Management. Assistant professor at the Cracow University of Economics - Department of Entrepreneurship and Innovation. Her scientific interests focus on innovation process issues, innovative potential of enterprises, conditions for innovativeness, management and entrepreneurship, especially in small and medium-sized enterprises. She is a member of the Scientific Committee of the National Entrepreneurship Contest. She is the scientific supervisor of the Students Scientific Club for Entrepreneurship and Innovation as well as the students' apprenticeship coordinator. She is the editorial secretary of the scientific quarterly 'Entrepreneurial Business and Economics Review' (EBER).

\section{Adress:}

Uniwersytet Ekonomiczny w Krakowie

Katedra Przedsiębiorczości i Innowacji

ul. Rakowicka 27, 31-510 Kraków, Polska

e-mail: kosalam@uek.krakow.pl 